\begin{tabular}{l|l} 
& $\begin{array}{l}\text { Eastern } \\
\text { European } \\
\text { Countryside }\end{array}$ \\
\hline DOI.1515/eec-2015-0013 & $21^{\prime} 2015$
\end{tabular}

Grzegorz Zabłocki

\title{
Department of the Sociology of Rural Areas of Nicolaus Copernicus University in Toruń
}

Zakład Socjologii Obszarów Rustykalnych [the Department of the Sociology of Rural Areas] came into existence in 1995 as a part of Institute of Sociology of Nicolaus Copernicus University in Toruń. However, works in the field of the rural sociology were undertaken in Torun already more than twenty years earlier, in Research Station of The Institute of Rural and Agricultural Development of the Polish Academy of Sciences that exists in this town since 1972 and in the Department of Sociology created in 1976 at Nicolaus Copernicus University. The spectacular achievement of this environment was playing the role of the host of the 4th World Congress of Rural Sociology, organized in 1976, and calling into existence Postgraduate Studies of the Rural Sociology in 1982, existing intermittently up till now. To these activities greatly contributed: Professor Zbigniew Wierzbicki, the worker of the Institute of Philosophy and Sociology Of the Polish Academy of Sciences, who in the eighties had taken up the job at Nicolaus Copernicus University, and Professor Włodzimierz Wincławski, who was then the head of Zakładem Socjologii the Department of Sociology, and then (from 1984) the head of the Chair of Sociology, which was transformed into the Institute of Sociology in 1995. This development was connected with the strive of the workers of the Department of Sociology and then the Chair of Sociology for launching MA Sociology studies at Nicolaus Copernicus University, which was achieved in 1989.

Professor Andrzej Kaleta was the head of the Department of the Sociology of Rural Areas for twenty years; continuously working at 
Nicolaus Copernicus University from 1976 and for nearly forty years initiating and coordinating the majority of activities connected with the rural sociology in Toruń. He was (for several years) the head of the Postgraduate Studies of the Rural Sociology; the originator and editor of two publishing series - 'Socjologia i Socjologowie' [Sociology and Sociologists], presenting achievements of the rural sociology in the selected countries (Romania, Slovakia, Germany, France, Austria, USA, Switzerland and Ireland), and the series 'Rewitalizacja obszarów rustykalnych Europy' [The Revitalization of Rural Areas in Europe]; the editor of the book summarising 40 years of the existence of sociology at Nicolaus Copernicus University and works of this team for the rural sociology in Central Europe (Kaleta 2012); the co-ordinator of many team research projects developed in cooperation with numerous foreign scientific centres and the inspirer of constant cooperation with valued foreign researchers of social processes concerning the village and agriculture such as: N. Swain, G. Vonderach, Ch. Giordano, L. Laschewski, M. Lostak; the originator (together with B. Weber, R. Borowicz and W. Pevetz) and the editor-in-chief of the yearbook 'Eastern European Countryside' for twenty years, the periodical created at the Department of the Sociology of Rural Areas, that is on the prestigious 'the International Science Index Master Journal List of scientific journals for several years now. Moreover, he was the originator and organiser of the speciality 'Polityka rozwoju obszarów wiejskich Europy' [Rural development Policy of Europe], created in the field of study of sociology at Nicolaus Copernicus University at the end of the nineties and carried up till now, and also the time-consuming preparations to launch the international studies 'European Masters for Rural Animators (EMRA)' at this university.

At present, the Department of the Sociology of Rural Areas consists of 6 workers (apart from Professor Andrzej Kaleta): dr Monika KwiecińskaZdrenka, dr Elwira Piszczek, dr Anna Pluskota, dr hab. Wojciech Knieć and dr hab. Grzegorz Zabłocki). The workers of the Department of the Sociology of Rural Areas in the period of the last twenty years were playing the essential roles in the authorities of The Section on Rural and Agriculture Sociology of the Polish Sociological Association, the European Society for Rural Sociology, the European Sociological Association, the European Council for the Village and Small Town and Euracademy Association, they took part in the works of the institutions managing the policy towards the village and agriculture - Polish Ministry of Agriculture and Rural 
Development and European Committee of the Regions, they were members of the scientific councils of Polish, German and Hungarian periodicals 'Roczniki Socjologii Wsi'[Rural Sociology Annuals], 'Wieś i Rolnictwo [the Village and Agriculture]', 'Land Berichte,' 'Regional Statistics', and also the Scientific Council of Polish Centre for Public Opinion Research. At the same time, the workers of the Department played the roles of experts in the institutions managing the activities towards rural environments and agriculture in Poland and in institutions influencing on the functioning of the rural environments in EU. They run the didactic activity and taught the Postgraduate Studies of the Rural Sociology, transformed later into the Postgraduate Studies of Governance of Local communities, and at the first cycle studies at the specialisation on 'Rural development Policy of Europe. Their graduates are on the whole several hundred, from which the part has made use of the obtained knowledge working in institutions that execute or shape the policy towards the rural areas and agriculture.

At that time, the workers of the Department took part in many international and national scientific researches (executed among others within the Framework of the research programmes of the European Union Or the World Bank). They presented the results of these researches during the international conferences regarding the rural sociology (including European and world's Kongresach Socjologii Wsi [Congresses of the Rural Sociology]) and in numerous scientific publications. Many of them concerned the two thematic scopes:

- social-economic changes on the rural areas of Central and East Europe, including the changes of the conditions and quality of life of the inhabitants of the village including among others the phenomena of: social inequalities, poverty, unemployment, social exclusion and helplessness (Hałasiewicz and Kaleta 1997; Zabłocki 1997; Kaleta 1998; Knieć 1999; Zabłocki, Sobczak, Piszczek and Kwiecińska 1999; Kaleta, Swain, Weber and Zabłocki 2001; Kwiecińska-Zdrenka 2004; Zabłocki 2004; Pluskota-Lewandowska 2005; Knieć and Małecka-Dobrogowska 2006; Kwiecińska-Zdrenka 2006; Knieć and Goszczyński 2010; Kwiecińska-Zdrenka 2010a; Kwiecińska-Zdrenka 2010b; Kwiecińska-Zdrenka 2010c; PluskotaLewandowska 2010; Knieć 2012; Pluskota 2012; Knieć, Goszczyński and Obracht-Prondzyński 2013; Piszczek 2013; Pluskota 2013; Kaleta 2014; Pluskota and Staszewicz 2014). 
- the condition of the rural sociology in Europe (Kaleta 1992; Kaleta 1994; Kaleta, Giordano and Preiswerk 1998; Knieć 2002; Piszczek 2005; Kaleta and Vonderach 2006; Piszczek 2008; Piszczek 2011; Kaleta 2012; Piszczek and Vonderach 2013; Kaleta 2013a; Kaleta 2013b; Zabłocki 2013; Zabłocki 2014).

The main reason for the intense observation of changes in conditions and quality of the life of the rural population in Central and East Europe was that in the last decade of the twentieth century in many countries of this part of the continent had occurred the change of the political system and a broad-based process of the privatization of the economy. These processes were accompanied by diverse social expectations, which confronting with the actually achieved effects was one of the then significant tasks of the social studies in countries subject to these changes. For better understanding of these processes, the essential was to reach for the results of the researches conducted in all the countries of that region and the achievements of rural sociologists also outside the region.

The works carried out at the Department of the Sociology of Rural Areas were not only limited to the observation of social and economic changes and the description of perceived regularities, but also attempts at checking the usefulness of given theoretical conceptions for solving problems of the inhabitants of the rural areas. The subject of these long-term works were among others the conceptions of activisation and revitalization of the local communities, and their effect was the publishing series The Revitalization of Rural Areas in Europe. Other example of such activities of the workers of the Department were the analyses of the possibilities of using the conception of the sustainable development, the social capital, education through the whole life and creating social networks and information technologies for better working conditions and the quality of life of the inhabitants of the rural areas. The effects of these analyses have been presented among others in the scientific publications enumerated at the end of this note.

Recently, dr hab. Wojciech Knieć has become the head of the Department of the Sociology of Rural Areas], and editor-in-chief of the periodical 'Eastern European Countryside' - dr Monika Kwiecińska-Zdrenka. Additionally, lately the workers of the Department (and the Laboratory of Telematics and Completion of Researches ) have completed, coordinated by prof. Andrzej Kaleta, long-term preparations to launch second-circle studies in the field of study: European Masters for Rural Animators (EMRA), which are going 
to be carried out at Nicolaus Copernicus University together with a few foreign universities (from Estonia, Greece, Spain, Germany, Romania and Hungary) interested in education (in the manner of distance learning, in English)also people outside Europe, who would like to become professional animators of development of the rural areas. You can find more data on this topic on the website: [www.emra.umk.pl].

The Department of the Sociology of Rural Areas is organising in June in Torun the scientific conference 'Eastern European Countryside Revisited 25 years after the Transition' devoted to the contemporary social and economic processes taking place in the rural areas of Central and East Europe (see the note on the conference in this volume of the periodical). This conference, in the intention of the organisers, is the first in the series of the international conferences repeated every a few years, which are to sum up the scientific achievements of the rural and agricultural sociologists, interested in the rural areas in this part of Europe.

\section{References}

Hałasiewcz, A. and Kaleta, A. (1997), Wiejskie gospodarstwo domowe [Rural Household], Wrocław: Zakład Narodowy im. Ossolińskich

Kaleta, A., Giordano, Ch. and Preiswerk Y. (eds) (1998), Socjologia wsi w Szwajcarii [Rural Sociology in Switzerland], Toruń: Uniwersytet Mikołaja Kopernika

Kaleta, A., Swain, N., Weber, B. and Zabłocki, G. (eds) (2001), Rural and Agricultural Transformation in Central Europe, Wrocław: Zakład Narodowy im. Ossolińskich

Kaleta, A. and Vonderach, G. (eds) (2006), Nowa socjologia wsi w Niemczech [The New Rural Sociology in Germany], Toruń: Uniwersytet Mikołaja Kopernika

Kaleta, A. (ed.) (1992), Socjologia wsi w Republice Federalnej Niemiec [Rural Sociology in Federal Republic of Germany], Toruń: Uniwersytet Mikołaja Kopernika

Kaleta, A. (ed.) (1994), Socjologia wsi w Austrii [Rural Sociology in Austria], Toruń: Uniwersytet Mikołaja Kopernika

Kaleta, A. (1998), Aktywizacja społeczności lokalnych [The Activization of Local Communities], Wrocław: Zakład Narodowy im. Ossolińskich

Kaleta, A. (ed.) (2012), Cztery dekady socjologii na Uniwersytecie Mikołaja Kopernika. Socjologia i socjologowie wsi krajów Europy Środkowej [Four Decades 
of Sociology in Nicolaus Copernicus University. Rural Sociology and Sociologists of the Central Europe Countries], Toruń: Uniwersytet Mikołaja Kopernika

Kaleta, A. (2013a), 'Die polnische Landsoziologie in der Zeit des Systemwandels in theoretisch-methodologischer Perspektive' ['Polish Rural Sociology in the Time of System Change in Theroretical and Methodological Perspective'], Land Berichte. Sozialwissenschaftliches Journal, vol. 2, p. 8-26.

Kaleta, A. (2013b), 'Obszary badawcze polskiej socjologii wsi okresu przejścia systemowego (lata 1989-2013)' ['Areas of Research of Polisch Rural Soiology in the Period of Sysytem Transformation (years 1989-2013)'], Roczniki Historii Socjologii, vol. 3, p. 127-154.

Kaleta, A. (2014), 'E-learning jako dyfuzja innowacji na obszarach wiejskich Unii Europejskiej' ['E-learning as a Dissemination of Innovation on Rural Areas of European Union'], Kultura i Edukacja, vol. 2, p. 134-145.

Knieć, W. and Goszczyński W. (2010) 'Rolnictwo w sieci - alternatywne sieci produkcji i dystrybucji żywności' ['Agriculture in Network - Alternative Networks of Food Production and Distribution'], Wieś i Rolnictwo, vol. 2, p. 49-64.

Knieć, W., Goszczyński, W. and Obracht-Prondzyński C. (2013), Kapitał społeczny wsi pomorskiej [Social Capital of Pomerania Willages], Wieżyca: Kaszubski Uniwersytet Ludowy.

Knieć, W. and Małecka-Dobrogowska, M. (2006), Potrzeby edukacyjne mieszkańców obszarów wiejskich Podlasia [Educational Needs of Inhabitants of Rural Areas in Eastern Poland], Białystok: Biuro Inicjatyw Rozwojowych.

Knieć, W. (1999), 'Cud w Kilitmagh. Udana akcja rewitalizacji wiejskiej społeczności lokalnej w Irlandii' ['Miracle in Kilitmagh. Successful Process of Revitalization of Local Rural Community in Ireland'], Wieś $i$ Rolnictwo, vol. 3, p. 49-61.

Knieć, W. (ed.) (2002), Socjologia wsi w Irlandii [Rural Sociology in Ireland], Toruń: Uniwersytet Mikołaja Kopernika

Knieć, W. (2012) Wspólna Polityka Rolna a zrównoważony rozwój obszarów wiejskich Polski [Common Agricultural Policy and Sustainable Development of Rural Areas in Poland], Toruń: Uniwersytet Mikołaja Kopernika

Kwiecińska-Zdrenka, M. (2004) Aktywni czy bezradni wobec własnej przyszłości? Młodzież wiejska na tle ogótu młodzieży [Helpless or Active? Portrait of Rural Youth], Toruń: Uniwersytet Mikołaja Kopernika

Kwiecińska-Zdrenka, M. (2006) Fenomen bezradności w ujęciach socjologicznych $i$ psychologicznych [Phenomenon of Helplessness in Sociological and Psychological Perspectives], in: Z. Gajdzica and M. Rembierz (eds) Bezradność. 
Interdyscyplinarne studium zjawiska $w$ kontekście zmiany edukacyjnej i społecznej, Katowice: Uniwersytet Śląski, p. 35-61.

Kwiecińska-Zdrenka, M. (2010a) Prawa podstawowe kobiet wiejskich w Polsce. Odcienie marginalizacji [Fundamental Laws of Rural Women in Poland], Toruń: Uniwersytet Mikołaja Kopernika

Kwiecińska-Zdrenka, M. (2010b), 'Der Beitrag von Frauenaktivitäten zum sozialen Wandel in ländlichen Regionen Polens' ['About Women Activity in Social Change in Rural Regions in Poland'], Land Berichte. Sozialwissenschaftliches Journal, vol. 2, p. 34-48.

Kwiecińska-Zdrenka, M. (2010c), Kinship and Social Security in Rural Poland, in: P. Heady and P. Schweitzer (eds), Eighteen Localities: Family, Kinship and Community at the Start of the 21st Century, Berlin: Max Planck Institute, p. 331-391 .

Piszczek, E. and Vonderach, G. (eds) (2013), Niemiecka socjologia wsi pierwszej dekady XXI wieku [German Rural Sociology of the First Decade of XXI Century], Toruń: Uniwersytet Mikołaja Kopernika

Piszczek, E. (2005), 'New Areas of Research in German Rural Sociology', Eastern European Countryside, vol. 11, p. 127-133.

Piszczek, E. (2008), Ländlichkeit als wissenschaftlich nützlicher Begriff [Rurality as a Scientific Usefull Term], in: L. Laschewski, A. Kaleta and K. Gorlach (eds) Neue Landsoziologie in Polend und Deutschland, Aachen: Shaker, p. 105-116 .

Piszczek, E. (2011), 'Tradition and Modernity in South-Eastern Europe - the Balkan Countries' search for their own way of Social Development in a Modern, United Europe', Eastern European Countryside, vol. 17, p. 151-158.

Piszczek, E. (2013), 'Life and Work in Rural Germany', Eastern European Countryside, vol. 19, p. 251-259.

Pluskota, A. and Staszewicz, M. (2014), 'Całożyciowe uczenie się drogą do inkluzji społecznej. Nieco rozważań krytycznych' [Lifelong learning as a Way to Social Inclusion], Teraźniejszość, Człowiek, Edukacja, vol. 66(2), p. 39-53.

Pluskota, A. (2012), 'The Multidimensionality and Ambivalence of Inequality and Diversity in European Rural Areas', Eastern European Countryside, vol. 18, p. 161-168. [DOI: 10.2478/v10130-012-0010-y]

Pluskota, A. (2013), 'W kierunku empowerment' ['In Direction to Empowerment'], Kultura i Edukacja, vol. 4, p. 70-92. 
Pluskota-Lewandowska, A. (2005), 'Central and Eastern European Counrtyside and Agriculture from the Japanese Perspective', Eastern European Countryside, vol. 11, p. 145-154.

Pluskota-Lewandowska, A. (2010), 'Lifelong learning for inclusion - between theory and practice, Eastern European Countryside, vol. 16, p. 115-130. [DOI: 10.2478/v10130-010-0006-4]

Zabłocki, G., Sobczak, M., Piszczek, E. and Kwiecińska, M. (1999), Ubóstwo na terenach wiejskich pótnocnej Polski [Poverty on Rural Areas of Northern Poland], Toruń: Uniwersytet Mikołaja Kopernika.

Zabłocki, G. (1997), 'Źródła bezrobocia na wsi' [Causes of Unemployment in Rural Areas], Wieś i Rolnictwo, vol. 3, p. 65-74.

Zabłocki, G. (2004), 'Accessibility to Secondary and Higher Levels of Education to Rural Young People', Wieś i Rolnictwo - Suplement to vol. 124 (3), p. 136-152 .

Zabłocki, G. (2013), 'The State of Rural Sociology as Presented in Four Periodicals Rural Sociology, Sociologia Ruralis, Journal of Rural Studies, Eastern European Countryside', Eastern European Countryside, vol. 19, p. 9-27. [DOI: 10.2478/ eec-2013-0002]

Zabłocki, G. (2014), 'Od „światowej socjologii wsi” do polityki wobec nauk społecznych i humanistycznych' ['From „Global Rural Sociology” to Politics Concerned with Social and Human Sciences'], Wieś i Rolnictwo, vol. 1, p. 185-195 . 